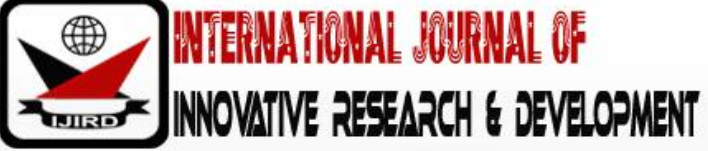

ISSN 2278 - 0211 (Online)

\section{Triggers of Informal Land Supply Dominance in Nigerian Cities}

Daniel Adamu
Lecturer, Department of Urban and Regional Planning,
Nasarawa State University, Keffi, Nigeria
Austine Audu Danladi
Area Town Planning Officer, Department of Development Control,
Nasarawa State Urban Development Board, Nigeria

\begin{abstract}
There has been exponential increase in the demand for informal land by prospective home owners and investors especially in most Nigeria cities. This is made possible as a result of several factors; the failure of formal system to provide land that is affordable and easily accessible, administrative and bureaucratic bottlenecks in the allocation of land, as outlined in some literatures. This study therefore, identified more of these factors that triggers the dominance of the informal delivery channels in Nigeria. Quantitative approach was deployed in measuring this variable even though some other elements could also be explained qualitatively. The instrument used in acquiring data was the questionnaire, summing-up to 310 distributed amongst household owners who were approached by the researchers to document their opinions in the five districts that made up the Karu Urban Area (KUA). Purposive method was applied in the distribution of the questionnaire as earlier outlined to only those who own the houses they were occupying. Data obtained were analyzed and presented in frequency tables. Factors such as paucity of formal land, affordability, user friendliness (flexibility of plot sizes and promptness to access land through the informal channel) and improvement in legal legitimacy/ tenure security are the major determining factors that have contributed to households' decision or preference for informal access to land. The study concludes and recommended that, the attributes of the informal land delivery system have presented better options to land accessibility than the formal market in most if not all the Nigeria urban centres, thus validating some earlier held findings in literature. However, minimum and realistic development standards can be set to ensure effective accessibility, and sustainability of the already dual land management system in cities.
\end{abstract}

Keywords: Dominance, informal channels, land delivery

\section{Introduction}

Land is one of the major natural resources bequeathed to man for his existence. It is an undeniable fact that virtually all human activities take place on land. Most importantly urban development activities such as housing, which provide shelter for man, all other land uses. The provision of most services for urban development is dependent, first and foremost on the availability of land. For Aluko and Moss (2002), access to land is a major problem. Every developing city is facing this problem due to population explosion. Another reason is urbanization which demands a lot of lands. Provision of urban land is under government's sole authority in Nigeria with negligible responsibility from state. Numerous numbers of studies have mentioned that like Nigeria many countries' land delivery system face a failure. Failure of formal channel increases demand for informal. As a result, for vertical and horizontal growth is taking place. For urban economy major constraint is lack of access to land. Access to building land has been identified as a serious problem as per the Presidential Committee on Urban Development and Housing, [2002]. Being the gateway city, Karu has suffered from the pressure of globalization, urbanization. Land markets come with many types of risks like, duration security, informal rights, inadequate compensation etc. According to Kwame and Antwi (2004), double sale is another major problem. Tema, Accra and Kumasi are the most sufferers for this problem. Rakodi and Leduka (2005), highlighted insecure tenure rights and property delineations are some of the other challenges. Instead of this urban families still looking for informal transfer and acquire of rights. Sometimes urban household are showing interest for formal land markets. This study focuses on the logic for finding substitute origin for residential land in Nigeria.

\subsection{What is Informal Land Delivery?}

"Informal" is used to express a wide range of operations vary situation and context wise. It is also known as "neocustomary", "quasi-customary", "living law" etc. UN-Habitat (2010). The term informal urban land delivery system is used to talk about a variety of urban land transactions, exchanges and transfers that are not recognized by the state as legal, but which are nevertheless socially acceptable as legitimate by a variety of urban actors. Antwi (2002), defined informal land deliver as transactions in land outside the government legal system for which the necessary government proscriptions for 
formalizations have not been met. Kironde (1995) defined informal land delivery as a delivery system where the allocation or transference of land is outside the ambit of the procedures laid down by the government.

Generally, such type of land is privately owned by people such as earlier occupation, virtue of customary tenure and transaction process is unplanned in nature. To match urban market style informal land markets are of hybrid types consisting of many operations, social practices, laws etc. As per law, this market needs to be involved about its functions. This study focuses on informal land delivery system that estranges, assigned and arbitrate land related transactions abide by social practices. There are many components including state officials, leaders, councilors, and families etc., to guide, synchronize, and adjudicate informal land delivery system. Informal channel at the same time can be restrictive or very much helpful for poor to solve land related problems. Just like formal structures and rules it may fall down also.

\subsection{Why Informal Land Markets Flourish in Nigeria}

Samuel A O. etal (2011), provided many reasons for the dominance nature of informal land delivery system in Nigeria over formal one. According to authors, formal markets have forced urban people to find residential land by their own initiative, which improves the acceptance for informal land delivery system. Scope for informal land delivery system varies from one country to another. Adamu (2015), discussed the economic nature of informal land delivery system in most of the cities of Sub-Sahara Africa especially at urban belts. Transaction of informal land delivery system is not registered under city authorities. This arises question about its quality and infrastructure. The provision of cutting corners and costs help to grow its operations and making it more affordable, accessible among other housing options. According to Adamu (2015), through this channel at a cheap rate and minimum facility shelters can be arranged. More facilities are need to be incorporated by residents own devices at later dates. In informal land market, depending on culture and traditions informal land market varies. All local leaders have the right to decide use to which land under their care is put. First all the basic needs like access to transport, roads are being fulfilled. The second important demand is fulfillment of water supply. Third is electricity connection and last is garbage cleaning facility, which is not under top-most priority list (Adamu, 2015).

\subsection{Empirical Studies of Informal Land Delivery}

Many studies are there to find out the logic behind preference for informal land delivery system. Success stories have been highlighted by Keivani, Mattingly, and Majedi (2008), after conducting research on Iran, Singapore, and Netherlands and Finland. This study mentioned that in Iran success was achieved by arranging house for low income group people. Through public-private joint venture schemes, Iran government can achieve this. This has established itself as a more successful approach for poor people, rather than depend only on market forces. Another study mentioned the success story of Kampala, east Africa where informal settlements have been achieved through regulation and structuring of the land delivery processes of informal settlements. Nkurunziza (2007), mentioned that different normative regulations can oppress market exchange and customary practices, which are involved in land delivery systems. Similarly, another study carried assesed the level of low-income householdsand communities in accessing land for housing deliveryin Dar es Salaam and discovered that most land is owned by the minority while majority declared willingness to aquire plots of land(Kironde, 1995). The study further explained that the poor have a better chance of accessing urban land if the efforts of different actors involved in informal land delivery and system is well harnessed.It is also argued that informal land and housing development is a manifestation of the absence of favourable laws and bureaucratic frameworks for formal land delivery system (Masum, Chigbu, Espinoza and Graefen 2016). They added that government should deal with such problems through a preventive approach by taking the initiative to develop a pro-poor land development policy. A propoor land development policy will be effective because if item braces poverty alleviating features and will constitute a bridge between formal and informal land delivery systems (Masum et al., 2016). Study conducted by Durand-Lasserve (2006), have highlighted that due to excessive demand for housing, formal land delivery system is facing failure. Self-help housing and squatting are being taken to solve this problem. Self-help housing is a very successful step in developing countries. Antwi (2002) has mentioned the informal channel as an optimal solution for residential problem against formal system. For Rakodi (2005), studies based on Tanzania, Vietnam, Ecuador and Ghana are showing continuous preference for informal land delivery systems. As per Omirin (2002), for acquiring land accessibility, affordability, availability and flexibility are the most important factors. Needless to say, like low income group majority of urban residents are looking for informal land delivery system. In southwest region of nigeria a study was carried out to identify problems associated with urban land acquisition for sustainable housing delivery in Akure with a view of arriving at means of mitigating them, it was revealed that accessing land for housing delivery in Akure is becoming highly problematic owing to increasing population growth and informal land delivery system. There is growing tendency during some years real estate investors are showing preference for informal land market in south-western towns and cities in Nigeria (Oloyede et al., 2011). Failure of the land use decree of 1978 can be its major reason. The land problem of Nigeria can be increase due to political issues compared to technical one. Adamu (2011) mentioned that more than $80 \%$ of supplied land in Karu Urban Area, have been used for residence in Karu Urban Area.

\subsection{Triggers of Access to Urban Land through Informal Channels}

Informal land delivery system has got popularity because of its ambivalent characteristics. According to Shien (2016), too much dependence on non-accepted policies by public institutions is one of the important reasons to adopt informal one by poor and middle-class income group. According to Gondo (2009), depend on administrative vulnerability to place priority for low density lands is another reason behind preference for unrealistic urban lands. Moreover, long waiting time is the major drawback. These trends have therefore promoted the marginalization of lower-income earners, 
increased cost of land, politicization and corruption of the delivery. Another pertinent justification for the choice of informal land access is that, the informal markets offer access to affordable sites in the way of lower cost of land for lower income earners and a loose off from the rigid and centralized land use control of the formal market which allows for flexibility of plots size, price discrimination and consequently encourages incremental payment, hence making it attractive (Oloyede, Osmond and Ayedum2011). Another interesting perspective presented economic performance in relation to increasing poverty, high level unemployment resulting in poor, which could not support the access to formal land delivery system (Lamba, 2005 and Mudalige, 2007). It had been believed that until the poor or equality will exist in the society the demand for informal land markets will be strong as they have maximum reference for this. With the help of assertion of ownership, agreement letters, informal channel is gaining popularity as well as security. According to Rakodi (2007), userfriendliness and adaptability with culture, social, laws improve the preference for informal land delivery system. Measures taken by informal channels which are discussed above help to increase accessibility, timeliness and tightened administration. Security has been tightened by this channel as the time is going occur (Chung and Hill, 2002; Chand and Yala, 2006). This is the reason why many families are getting encouragement to adopt informal land delivery system.

\begin{tabular}{|c|c|c|c|}
\hline $\mathbf{S} / \mathbf{N}$ & Triggers & Cause & Effects \\
\hline 1 & $\begin{array}{l}\text { Ambiguous Formal } \\
\text { institutions } \\
\text {-unrealistic urban } \\
\text { land use } \\
\text { regulation/ standards } \\
\text {-bureaucratic } \\
\text { susceptibility } \\
\text {-weak institutions }\end{array}$ & $\begin{array}{l}\text {-Do not capture the yearnings of the } \\
\text { majority (middle/ low income earners) } \\
\text {-Formal delivery largely prioritize (low } \\
\text { density plot sizes for higher income } \\
\text { earners) } \\
\text {-Administrative bottlenecks and long } \\
\text { waiting time for accessing formal land }\end{array}$ & $\begin{array}{c}\text {-Poor social legitimacy } \\
\text {-Marginalization of lower } \\
\text { income earners and increasing } \\
\text { cost of land } \\
\text {-Politicization and corruption } \\
\text { of the delivery }\end{array}$ \\
\hline 2 & $\begin{array}{l}\text { Affordability of } \\
\text { informal land }\end{array}$ & $\begin{array}{l}\text {-Lower cost compares to formal land } \\
\text {-Flexible land price } \\
\text {-Price discrimination }\end{array}$ & $\begin{array}{l}\text {-Accessible to lower income } \\
\text { earners } \\
\text {-Incremental payment }\end{array}$ \\
\hline 3 & $\begin{array}{l}\text { Economic } \\
\text { performance }\end{array}$ & $\begin{array}{l}\text { Increasing poverty, higher level } \\
\text { unemployment, Low income }\end{array}$ & $\begin{array}{l}\text { Increasing preference for } \\
\text { informal land }\end{array}$ \\
\hline 4 & $\begin{array}{l}\text { Gradual improvement } \\
\text { in legal } \\
\text { legitimacy/tenure } \\
\text { security }\end{array}$ & $\begin{array}{c}\text { Use of witnesses } \\
\text { Affirmation of transaction by traditional } \\
\text { authorities } \\
\text { Letter of agreement }\end{array}$ & Improving tenure security \\
\hline 5 & $\begin{array}{l}\text { User friendliness and } \\
\text { social legitimacy }\end{array}$ & $\begin{array}{c}\text { Flexibility of plot sizes } \\
\text { Absence of bureaucracy } \\
\text { Historical/ cultural antecedents }\end{array}$ & $\begin{array}{c}\text {-Timely } \\
\text { accessibility/ possession } \\
\text {-Community driven } \\
\text {-Locally administered }\end{array}$ \\
\hline 6 & $\begin{array}{l}\text { Enhances social } \\
\text { cohesion }\end{array}$ & $\begin{array}{l}\text { Allowance for group/ cooperative } \\
\text { purchase e.g. by ethnicity, religious, } \\
\text { professional, organizational access }\end{array}$ & $\begin{array}{l}\text { Build ties amongst different } \\
\text { groups }\end{array}$ \\
\hline
\end{tabular}

\section{Table 1}

Source: Authors Modification, 2019 Inspired by the Works of Other Researchers (See, Shien 2016; Gondo 2009; Oloyede, Osmond and Ayedum, 2011; Lamba2005; Mudalige2007; Rakodi2007; Chung and Hill, 2002; Chand and Yala, 2006)

\section{Methodology}

It is mostly a tasking venture in collecting data for research especially in most of our traditional Nigeria cities. The scenario is much more pronounced when embarking on study with little or no record base like informal land channel. Hence, to achieve our objectives, primary data were relied upon largely and a few document reviews of data from previous research collected from five of the Karu urban districts such as New Karu, Mararaba, Masaka, New Nyanya, and Ado. To achieve this, purposive sampling Technique was utilized for this research. All householders were eligible to answer the survey questionnaire; a sample size of 0.25 percent was adopted from the five districts of Karu Urban Area which gives an approximated value of 310 respondents used for the study. The sample size was arrived at using Taro Yemane formula. According to Yamene, the sample size of 0.1-.05 is recommended for carrying out research depending on the size of your sample frame. Hence, having a sample frame of 124,043 the sample size of 0.25 that falls within the recommended sample size was adopted. These 310 respondents were spread across the five districts of Karu Urban Area. The questions related to informal land process were drawn and administered in order to ascertain the influence of the Informal Land access on housing delivery on each stratum, by large the entire city. This is summarized in the table below: 


\begin{tabular}{|c|c|c|c|}
\hline Districts & $\begin{array}{c}\text { Projected } \\
\text { Population }\end{array}$ & $\begin{array}{c}\text { Household } \\
\text { Population }\end{array}$ & $\begin{array}{c}\text { Sample Size (\%) } \\
\text { (No of Respondents - Household Owners) }\end{array}$ \\
\hline Mararaba & 195,994 & 32,666 & 82 \\
\hline Kuruduma & 142,306 & 23,718 & 59 \\
\hline New Karu & 166,573 & 27,762 & 69 \\
\hline Ado & 70,050 & 11,675 & 29 \\
\hline Masaka & 169,333 & 28,222 & 71 \\
\hline Total & 744,256 & 124,043 & 310 \\
\hline
\end{tabular}

Table 2: Sample Distribution for Household Home Owners

Source: Authors Field work, 2016

\section{Result and Discussion}

Drawing from different perspectives reviewed and findings of this research, it is apparent that four major triggers are responsible for the dominance of informal land delivery in most developing countries cities and most especially Nigerian cities. These have been identified as; affordability for most urban residents, their user friendliness (in terms of flexible plot sizes unlike the rigidity in formal systems, promptness of possession once payments are made and opportunities for incremental payment), improvement in legal legitimacy/tenure security and paucity of formal land which makes them highly competitive. These have been presented in the discussion that follows.

\subsection{Triggers of Access to Land through Informal Channels in Karu}

Several determinant triggers have contributed in attracting house owners toward the informal land in most developing countries where the informal land has contributed the larger percentage of land for urban housing. The scenario is the same in Karu the gate city, where factors such as affordability, user friendliness, ambiguous formal institution, economic performance, gradual improvement in legal legitimacy/tenure security, and enhancement of social security, form the reasons developers prefer informal land to formal land. These triggers are analyzed below:

\subsubsection{Affordability}

Lower Cost of informal land in comparism with the formal land is a major trigger of access to land via informal channel. It was therefore necessary for this research to verified this assertion in Karu Urban area. The informal access in respect to urban development has made land relatively affordable. From table 3 below, we can deduce that the prices

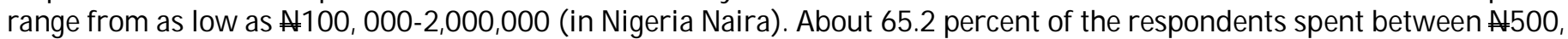
$000-\mathrm{N} 1,000,000$ to acquire their land via the informal channel. The price discrimination has provided a lease for urban developers to own land with little or no financial constraints. These variations are possible even within the same location; size of land, period of land acquisition, and channel of delivery among others depending on the purchaser's bargaining power and the owner's level of need. This revelation also buttresses several assertions made in literature that land affordability is a major factor that influence housing supply (Ifesanya, 2012).This supports the findings of (Leduka, 2006 and Rakodi, 2005), that informal land delivery provides access to land for housing development for the majority of people irrespective of their socioeconomic class.

\begin{tabular}{|c|c|c|c|c|c|c|c|}
\hline & New Karu & Kuruduma & Masaka & Mararaba & Ado & & \\
\hline Factor & $\begin{array}{c}\text { No. } \\
\text { of Response }\end{array}$ & $\begin{array}{c}\text { No. } \\
\text { of Response }\end{array}$ & $\begin{array}{c}\text { No. } \\
\text { of Response } \\
\end{array}$ & $\begin{array}{c}\text { No. } \\
\text { of Response }\end{array}$ & $\begin{array}{c}\text { No. } \\
\text { of Response }\end{array}$ & Total & $\%$ \\
\hline \multicolumn{8}{|l|}{$\begin{array}{c}\text { Cost } \\
\text { of PurchaseN }\end{array}$} \\
\hline 100,000 & - & 9 & 15 & 10 & 6 & 40 & 12.9 \\
\hline $\begin{array}{l}100,000- \\
499,000\end{array}$ & 19 & 11 & 19 & 27 & 8 & 84 & 27.1 \\
\hline $\begin{array}{l}500,000- \\
999,000\end{array}$ & 29 & 29 & 22 & 31 & 7 & 118 & 38.1 \\
\hline $\begin{array}{l}1,000,000- \\
2,000,000\end{array}$ & 21 & 10 & 15 & 14 & 8 & 68 & 21.9 \\
\hline Total & 69 & 59 & 71 & 82 & 29 & 310 & 100 \\
\hline
\end{tabular}

Table 3: Affordability

Source: Author's Computation, 2016

\subsection{User Friendliness of the Supply}

The informal channels or mechanisms have proven to be quite friendly to the needs and yearning of urban residents for the way and manner through which transactions in land is more tailored made and structured by the actors. That's to the needs and preferences of both buyers and sellers. These are in the forms of: flexibility of plot sizes, promptness of possession once payments are initiated or completed as well as opportunities for incremental payments depending on the factors of trust and reliability of arbitration mechanisms in place in any given community.

Flexible plot sizes 
An important user friendliness factor for informal access to land in Karu urban Area is the flexibility in terms of plot sizes. The Results in table 4.12 depicts that various sizes of plots are developed by different clients. Table 4 shows that $63.4 \%$ of the 238 household owners said that their developed plot size ranges between 450sqm-900sqm. This indicates that most of the developed lands by individual household owners in the study area are less than 900sqm and most land developed by developers are in hectares. The implication is that these different sizes of plots developed are a product of magnitude of use, status and ability to purchase. However, this also informs the flexible pattern of accessing plot land through the informal channel as against the rigid nature associated with the formal channel.

\begin{tabular}{|c|c|c|c|c|c|c|c|}
\hline & New Karu & Kuruduma & Masaka & Mararaba & Ado & & \\
\hline Factor & $\begin{array}{c}\text { No. } \\
\text { of Response }\end{array}$ & $\begin{array}{c}\text { No. } \\
\text { of Response }\end{array}$ & $\begin{array}{c}\text { No. } \\
\text { of Response }\end{array}$ & $\begin{array}{c}\text { No. } \\
\text { of Response }\end{array}$ & $\begin{array}{c}\text { No. } \\
\text { of Response }\end{array}$ & Total & $\%$ \\
\hline \multicolumn{8}{|l|}{ Plot in Sqm } \\
\hline 225 & - & 9 & 15 & 10 & 6 & 40 & 12.9 \\
\hline $450-900$ & 19 & 11 & 19 & 27 & 8 & 84 & 27.1 \\
\hline $1350-1800$ & 29 & 29 & 22 & 31 & 7 & 118 & 38.1 \\
\hline $2250-2500$ & 21 & 10 & 15 & 14 & 8 & 68 & 21.9 \\
\hline Total & 69 & 59 & 71 & 82 & 29 & 310 & 100 \\
\hline
\end{tabular}

Table 4: Flexible Plot Sizes

Source: Author's Computation, 2016

\subsubsection{Promptness of Possession}

Observations from the field depicts that promptness is a major determinant factor that attracts house owners toward accessing land for housing development through the informal channel. From the Table 5, we could clearly see that $47.4 \%$ of the respondents took less than a month, in possessing their land while $30.4 \%$ took between $1-5$ months to acquire and full possession of their plot of land while $14.8 \%$ took 6 months to 1year to acquire their plots. However, only $7.4 \%$ spent more than a year and above to acquire their plots for housing. This variations in period of payment is attributed to the fact that informal land delivery channel allows for incremental payment for land acquisition. This clearly shows the respondents preference for informal land as it requires less time needed and allows for installment payment to access land. The above scenario in Karu has actually buttressed the claim made by scholars in literature. (Gondo, 2009), noted that the informal land delivery channels do not just avail significant supply of residential land but tended to provide solution to the unrealistic urban lands use regulations and standards as well as their bureaucratic susceptibility

\begin{tabular}{|c|c|c|c|c|c|c|c|}
\hline & New Karu & Kuruduma & Masaka & Mararaba & Ado & & \\
\hline Triggers & $\begin{array}{c}\text { No. } \\
\text { of Response }\end{array}$ & $\begin{array}{c}\text { No. } \\
\text { of Response }\end{array}$ & $\begin{array}{c}\text { No. } \\
\text { of Response }\end{array}$ & $\begin{array}{c}\text { No. } \\
\text { of Response }\end{array}$ & $\begin{array}{c}\text { No. } \\
\text { of Response }\end{array}$ & Total & $\%$ \\
\hline \multicolumn{8}{|l|}{ Period spent } \\
\hline$<1$ month & 28 & 33 & 34 & 36 & 16 & 147 & 47.4 \\
\hline 1-5months & 22 & 16 & 25 & 22 & 9 & 94 & 30.4 \\
\hline 6months-1yr & 9 & 10 & 12 & 11 & 4 & 46 & 14.8 \\
\hline Above 1yr & 10 & - & - & 13 & - & 23 & 7.4 \\
\hline Total & 69 & 59 & 71 & 82 & 29 & 310 & 100 \\
\hline
\end{tabular}

Table 5: Promptness of Possession

Source: Author's Computation, 2016

\subsubsection{Incremental Payment}

One of the triggers that attracted some developers to access land through the informal channel is its ability to allow for flexible payment mode. From table $6,35.2 \%$ of the respondents attest to the fact that they made their payment in instalment as against $64.8 \%$ who made one-off payment to acquire their land. This confirmed the position of Adamu who opined that informal land delivery channel allows for incremental payment.

\begin{tabular}{|c|c|c|c|c|c|c|c|}
\hline & New Karu & New Nyanya & Masaka & Mararaba & Ado & & No. \\
\hline Triggers & $\begin{array}{c}\text { No. } \\
\text { of Response }\end{array}$ & $\begin{array}{c}\text { No. } \\
\text { of Response }\end{array}$ & $\begin{array}{c}\text { No. } \\
\text { of Response }\end{array}$ & $\begin{array}{c}\text { No. } \\
\text { of Response }\end{array}$ & $\begin{array}{c}\text { No. } \\
\text { of Response }\end{array}$ & Total & \% \\
\hline Mode of payment & 15 & 26 & 34 & 21 & 8 & 140 & 35.2 \\
\hline Incremental & 54 & 33 & 37 & 56 & 21 & 201 & 64.8 \\
\hline One-off & 69 & 59 & 71 & 82 & 29 & 310 & 100 \\
\hline Total & & & & & & & \\
\hline
\end{tabular}

Table 6: Incremental Payment

Source: Author's Computation, 2016

\subsection{Improvement in Legal Legitimacy/ Tenure Security}

Gradual improvement in legal legitimacy and tenure security of informal land is consequence of affirmation of ownership through the issuance of Letter of agreement which is a written document describing the intent of the seller to 
relinquish his right over a piece of land and an amount paid by the buyer to take over the right so relinquish by the seller, and this accounts for $61.3 \%$ as documents held over plots of land in the study area. $31.3 \%$ had change of ownership which is issued by Local Government as a certification that ownership of the land has been transferred from the seller to the buyer. However, $7.4 \%$ had right of occupancy ( $\mathrm{R}$ of $\mathrm{O}$ ) which is a preamble to final issuance of certificate of occupancy by the State Government.

\begin{tabular}{|c|c|c|c|c|c|c|c|}
\hline & New Karu & Kuruduma & Masaka & Mararaba & Ado & & \\
\hline Triggers & $\begin{array}{c}\text { No. } \\
\text { of Response }\end{array}$ & $\begin{array}{c}\text { No. } \\
\text { of Response }\end{array}$ & $\begin{array}{c}\text { No. } \\
\text { of Response }\end{array}$ & $\begin{array}{c}\text { No. } \\
\text { of Response }\end{array}$ & $\begin{array}{c}\text { No. } \\
\text { of Response }\end{array}$ & Total & $\%$ \\
\hline $\begin{array}{l}\text { Agreement } \\
\text { letter }\end{array}$ & 30 & 48 & 49 & 41 & 22 & 190 & 61.3 \\
\hline R of $O$ & 10 & & & 13 & & 23 & 7.4 \\
\hline $\begin{array}{l}\text { Change of } \\
\text { Ownership }\end{array}$ & 29 & 11 & 22 & 28 & 7 & 97 & 31.3 \\
\hline Total & 69 & 59 & 71 & 82 & 29 & 310 & 100 \\
\hline
\end{tabular}

Table 7: Supporting Documents

Source: Author's Computation, 2016

\subsection{Paucity of Formal Land}

In explaining the paucity of land as a determining factor for accessing informal land in Karu, the land supply ratio by the formal sector in Karu Urban Area. Available records from formal organizations responsible for formal land delivery shows that only five distinct layouts were prepared and implemented by the government of Nasarawa state; NIPDC (Nasarawa Investment and Property Development Company) also known as Abacha Estate 96 Ha, Penninsulate Estate 271Ha, GRA 322.55 Ha and Koroduma Estate 101.81Ha. The New Karu resettlement area was also planned and accounts for about 320 Ha (source: Nasarawa State urban Development Board). The total public controlled residential areas accounts for 1,111.36 Ha (Adamu, 2014).

The total built up area of Karu Urban Area (KUA) is estimated at 7,507.66Ha. Subtracting the public controlled area from the total built-up is 6,396Ha (63,960 plots of land, using standard measurement of $1000 \mathrm{~m} 2$ ) with the informal actors as dominant actors in its distribution. Although, other land-uses also form part of this chunk, it is obvious that residential land-uses is predominant in the area. This appraisal considered the land acquisition process, economic, and social implications of the informal land delivery system in KUA from the response of residents or property owners (Adamu, 2014).

Reasons for this short supply include:

- Long waiting time between expression of interest and actual possession of land to commence development averagely 8-10 years (Adamu, 2014)

- Excessive change and fees make such land unaffordable to the majority who are low income earners. This justifies the position of Lamba (2005) and Mudalife (2007) who posit that as "poverty continue to exist so will informalities" and this corresponds the finding of Adamu, (2014).

\section{Conclusion}

Due to high socio-economic inferences residential land is a very important factor for everyone. Many researches have focused on the importance of informal land access and factors influencing this. Like majority of Nigerian urban centres, Karu based informal land delivery system has proved itself a better option compared to formal one. Efficient management of administration of government has been swamped by the excessive demand for land in urban. Poor had suffered a lot as government was unable to provide land. The situation became more complex due to many rigid rules and standards. A study conducted by Shien (2016), revealed that shortcomings of institutions as well as inclination of families towards cultural, racial and religious norms have increased the liking for informal land access. Another study provided a suggestion to improve flexibility in formal land administration system. This seems to reduce corruption and increase more flexibility among local government. It is advisable to include community, family who own lands as stakeholders. Proper and pragmatic standardization is important to achieve effective penetrability. But most importantly, the social legitimacy and increasing legal prominence the informal systems seems to be gaining has necessitate its recognition as a locally effective land management system that resonates organically with the people. Thus, need to accept this duality in our land management and administration as viable alternative, as well as the need to strengthen some weakness where they occur.

\section{References}

i. Adamu, D., Kpalo, S. Y., Lay, U.S and Ojibo, S.D; (2015) Informal Land delivery system's dominance in urban land supply: benefits and consequences in Karu urban area. Nigerian Journal of Tropical Geography, 6, (1).

ii. Aluaigba, M. T. (2009). The Tiv-Jukun ethnic conflict and the citizen question in Nigeria. A Research Report, Kano, Nigeria. AminuKano Centre for Democratic Research and Training.

iii. Chand, S. and Yala, C. (2006), Informal land systems within Urban settlements in Honiara and Port Moresby, IDEC Working Papers 07/ 04, Canberra, Australia: Crawford School of Economics and Government, Australian National University. Available at www.crawford.anu.edu.au/degrees/idec/ working_papers/ IDEC07-04. pdf. Accessed 18th July, 2015. 
iv. Chung, M. and Hill, D. (2002). Urban informal settlements in Vanuatu: challenge for equitable development, report prepared for the Pacific Islands Forum Secretariat and UN Economic and Social Commission for Asia and the Pacific, Pacific Operations Centre.

v. Durand-Lasserve, A. (2005). Land for housing the poor in African cities, Are neo-customary processes an effective alternative to formal systems? In N. Hamdi (Ed.), Urban futures: Economic development and poverty reduction, pp. 122-138. London: ITDG Publishing.

vi. Gondo, T. (2009). Urban land and informality: An evaluation of institutional response options to land informalization in Ethiopian cities. Department of Urban and Regional Planning, University of Venda, Limpopo Province, South Africa.

vii. Keivani, R., Mattingly, M. \& Majedi, H. (2008). Public management of UrbanLand, Enabling Markets and Low Income Housing Provision: The Overlooked experience of Iran. Urban Studies, 45(9), 1825-1853.

viii. Kironde, J. M. (1995). Access to land by the urban poor in Tanzania: some findings from Dar es Salaam. Environment and Urbanization, 7(1), 77-96.

ix. Kwame, S. O. and Antwi, F. (2004). The impact of land delivery and finance on the supply of residential accommodation in the urban centres of Ghana: A case study of Accra, Tema and Kumasi. M.Sc. thesis submitted to the Department of Real Estate and Construction, Royal Institute of Technology, Stockholm, Sweden.

x. Lamba, A.O. (2005). Land tenure management systems in informal settlements: A case study of Nairobi. Being M.Sc. Thesis submitted to the International Institute for Geo-information Science and Earth Observation. Enscheda, the Netherlands.

xi. Leduka, C. (2006). Explaining informal land delivery processes andinstitutions in African cities: conceptual frameworkand emerging evidence. South African Review of Sociology, 37(1), 1-19.

xii. Masum, F., Chigbu, U. E., Espinoza, J., \& Graefen, C. (2016). The Limitations of Formal Land Delivery System: Need for a Propoorurban Land Development Policy in Dhaka, Bangladesh. 2016 World Bank Conference on Land and Poverty. Washington DC: The World Bank.

xiii. Mudalige, A. P. (2007). Impact of secure land tenure on income generating activities in urban informal settlements: A case of Dares Salaam, Tanzania. Being M.Sc. Thesis submitted to the International Institute for Geoinformation Science and Earth Observation. Enscheda, The Netherlands.

xiv. Nkurunziza, E. (2007). Informal mechanisms for accessingand securing urban land rights: thecase of Kampala, Uganda. Environment and Urbanization, 19(2), 509-526.

xv. Oloyede, S. A. etal (2007), Informal land delivery in Lagos State, Nigeria. Journal of Land Use and Development Studies, 3(1), pp. 140-146.

xvi. Oloyede, S.A. etal (2011). Informal land markets: Alternative approach to mass residential housing provision in South-Western Nigeria. Journal of Geography and Regional Planning, 4(11), pp. 598 - 603.

xvii. Omirin, M. M. (2002). Issues in Land Accessibility in Nigeria. Proceedings of a National Workshop on Land Management and Property Tax Reform in Nigeria. Lagos: Department of Estate Management, University of Lagos.

xviii. Oyedokun, T. B. Adewusi, A.O, Ojo, B, Onakoya, B.O, and Akinbogun, S.P. (2012). Constraints to land accessibility by urban residents in Akure, Nigeria. In Laryea, S.Agyepong, S.A., Leiringer, R. And Hughes, W. (Eds) 4th West African Built Environment Research (WABER) Conference, 24-26 July, 2012 Abuja, Nigeria. 1249- 1260.

xix. Rakodi, C. (2007). Land for housing in African cities: Are informal delivery systems institutionally robust and propoor? Global Urban Development. 3(11), Available at www.globalurban.org/GUDMag07vol3Iss/rakodi.htm Accessed $17^{\text {th }}$ October, 2009.

xx. Sivam, A. (2002). Constraints affecting the efficiency of the urban residential land market in developing countries: A Case study of India. Habitat International, 26(2), pp. 523-537.

xxi. Shien S. K (2016), Analysis of Urban Households' Preference for Informal Access to Residential Land in Minna, Nigeria. Journal of GJDS, 13(2) pp 84-99

xxii. UN-Habitat. (2010). Urban Land Markets: Economic Concepts and Tools for Engaging in Africa. Kenya: UN-Habitat. 